\section{A LINK BETWEEN PALEOCEANOGRAPHY, EARLY DIAGENETIC CEMENTATION, AND SHEAR STRENGTH MAXIMA IN LATE QUATERNARY DEEP-SEA SEDIMENTS?}

\author{
H. Kassens and M. Sarnthein \\ Geologisch-Paläontologisches Institut \\ Universität Kiel \\ Kiel, Federal Republic of Germany
}

Abstract. Near-surface sediments from the equatorial east Atlantic and the Norwegian Sea exhibit pronounced shear strength maxima in profiles from the peak Holocene and Pleistocene. These semi-indurated layers start to occur at 8-102 $\mathrm{cm}$ below the sediment surface and can be explained neither by the modal composition nor by the effective overburden pressure of the sediments. However, scanning electron microscope and microprobe data exhibit micritic crusts and crystal carpets, which are clearly restricted to (undisturbed) samples from indurated layers and form a manifest explanation for their origin. The minerals precipitated comprise calcite, aragonite, and in samples more proximal to the African continent $\mathrm{SiO}_{2}$ needles, and needles of as yet unidentified $\mathrm{K}-\mathrm{Mg}-\mathrm{Fe}-\mathrm{Al}$ silicates, crusts of which dominate the indurated layers in the Norwegian Sea. By their stratigraphic position in deep-sea sediments the carbonate-based shear strength maxima are tentatively ascribed to dissolved adjacent pteropod layers from the early Holocene and hence to short-lived no-analogue events of early diagenesis. Possibly, they have been controlled by a reduced

\section{Copyright 1989}

by the American Geophysical Union.

Paper number 89PA00114.

0883-8305/89/89PA-00114\$10.00 organic carbon flux, leading to increased aragonite preservation in the deep sea.

\section{INTRODUCTION}

In "normally" consolidated sediments shear strength is expected to gradually increase with sediment depth [Richards, 1962; Almagor, 1979]. However, the pelagic near-surface sediments of the equatorial and high-latitudinal North Atlantic (Figure 1) reveal different patterns and unexpected orders of magnitude of shear strength variation. Only few decimeters below the sediment surface, shear strengths already reach maximum values within distinct layers, which are a few tens of centimeters thick. Further below, on the other hand, they again decrease to amounts resembling those near the sediment surface. This distribution pattern was characteristic of altogether 34 box core profiles, a gravity core, and three kastencores obtained from the equatorial Atlantic [Sarnthein et al., 1983, 1985] and the Norwegian Sea [Gerlach et al., 1986]. On the basis of oxygen isotope stratigraphy and ${ }^{14} \mathrm{C}$ dating the sediment profiles of most box cores comprise approximately the time span since the Last Glacial Maximum. Hence, the uncommon shear strength maxima (SSM) are likely to parallel the first-order paleoceanographic events associated with the climatic optimum after the last glacial Termination [Berger, 1977; Broecker et al., 1988]. 

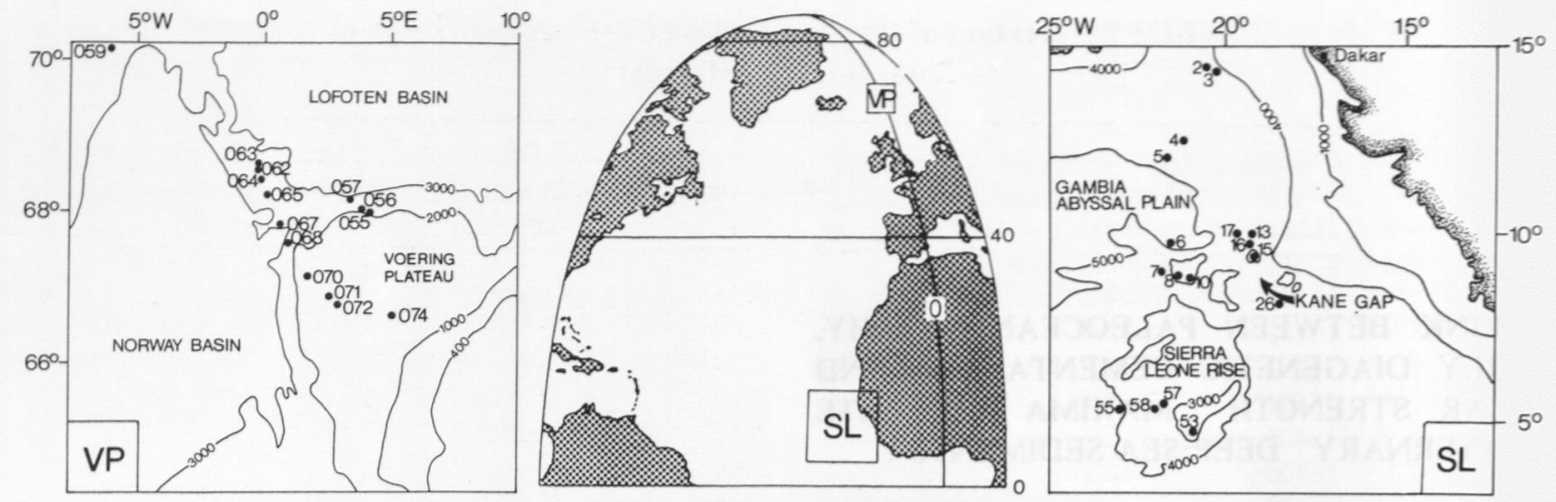

Fig. 1. Location of cores in the equatorial Atlantic and the Norwegian Sea.

In order to elucidate their possible origin, in this study we compare the shear strength maxima with the distribution pattern of generally essential physical sediment properties. However, only scanning electron microscope studies of the undisturbed sedimentary microfabrics led us to a breakthrough in the under-standing of this question.

\section{METHODS}

Sedimentological data and physical properties were measured on 140 samples from 22 box core sections, 90 samples from a $12 \mathrm{~m}$ long gravity core from the equatorial Atlantic, 400 samples from 12 box cores, and three kastencores out of the Norwegian Sea (Table 1; sample numbers will be abbreviated to the last two or three digits in the following text). The kastencorer is a gravity corer with a rectangular core barrel (cross-sectional area $900 \mathrm{~cm}^{2}$ ) [Kögler, 1963]. All cores were sampled immediately on board. Undrained shear strength was determined on both fresh, undisturbed core sections and remolded sediment samples by means of a Haake $R V 3$ "rotation shear apparatus" (viscosimeter) immediately after opening the cores on board R/V Meteor and R/V Polarstern [Kassens, 1985; Gerlach et al., 1986]. The reproducibility of this method is shown in Figure 4 by maximum, mean, and minimum values from up to five measurements at each depth level. Initially, our data were obtained from irregular downcore distances of 4 and $14 \mathrm{~cm}$ and later on from regular distances of $2.5 \mathrm{~cm}$. Organic carbon and carbonate carbon were measured at a Leco CS-244 instrument. Grain sizes coarser than $63 \mu \mathrm{m}$ were determined by sieve, and those finer than $63 \mu \mathrm{m}$ by means of a Sedigraph
$5000 \mathrm{D}$ analyzer [Stein, 1985] and by the standard pipette method. Water content, wet bulk density, grain density, and porosity were measured on cylinder samples of $10 \mathrm{~cm}^{3}$ following standard procedures [Richards, 1962; Boyce, 1976; Holler, 1985; Kassens, 1985].

In the beginning, our studies of undisturbed sedimentary fabrics under the electron microscope were based on samples which dried at room temperature. Later on the samples were kept in continuous deep freeze from the time of shipboard sampling until freeze drying in a desiccator. This avoided artificial mineral growth and the formation of cracks in the microstructure during sample drying. After drying, undisturbed sample pieces were fixed by glue and coated by carbon vapor on special trays for the scanning electron microscope. The mineral composition of the sample was estimated semiquantitatively by means of an EDAX (Energy Dispersive Analysis of X-rays) system. Moreover, a limited number of samples (e.g., from section 02) were analyzed quantitatively for the elemental composition of minerals of special interest at a Camebax Microbeam $C D$ microprobe (Mineralogisch-Petrographisches Institut, Universität Kiel). These data were determined from thin sections of artificially indurated sediment samples.

\section{AGE CONTROL}

The stratigraphy of all core sections was based on oxygen isotopic curves of Globigerinoides sacculifer and in many cases of Cibicidoides wuellerstorfi (in low latitudes) and Neogloboquadrina pachyderma left (in high latitudes) [E. Vogel- 
TABLE 1. Location of Cores, Including Core Depth and Age of Shear Strength Maxima

\begin{tabular}{|c|c|c|c|c|c|}
\hline Core & $\begin{array}{c}\text { Latitude, } \\
\text { north }\end{array}$ & Longitude & $\begin{array}{c}\text { Water Depth, } \\
\text { m }\end{array}$ & $\begin{array}{l}\text { Core Depth } \\
\text { of Spikes, } \\
\mathrm{cm}\end{array}$ & $\begin{array}{c}\text { Age } \\
\text { of Spikes, } \\
\text { ka }\end{array}$ \\
\hline $16401-2$ & $14^{\circ} 47.7^{\prime}$ & $20^{\circ} 30.7^{\prime} \mathrm{W}$ & 4061 & no spike & \\
\hline $16402-1$ & $14^{\circ} 25.0^{\prime}$ & $20^{\circ} 34.0^{\prime} \mathrm{W}$ & 4203 & $14.5-31.5$ & $4.7-8.1$ \\
\hline 16403-1 & $14^{\circ} 22.7^{\prime}$ & $20^{\circ} 32.1^{\prime} \mathrm{W}$ & 4234 & 21.5 & 7.95 \\
\hline 16404-1 & $12^{\circ} 40.3^{\prime}$ & $21^{\circ} 17.9^{\prime} \mathrm{W}$ & 4787 & $14.5-18.5$ & $6.9-8.1$ \\
\hline $16405-1$ & $12^{\circ} 15.6^{\prime}$ & $21^{\circ} 24.7^{\prime} \mathrm{W}$ & 4870 & 15.5 & 6.2 \\
\hline $16406-1$ & $09^{\circ} 51.8^{\prime}$ & $21^{\circ} 36.6^{\prime} \mathrm{W}$ & 5140 & no spike & \\
\hline 16407-1 & $09^{\circ} 02.4^{\prime}$ & $21^{\circ} 57.6^{\prime} \mathrm{W}$ & 4586 & 17.5 & 7.3 \\
\hline $16408-1$ & $09^{\circ} 00.8^{\prime}$ & $21^{\circ} 27.4^{\prime} \mathrm{W}$ & 4239 & 15.5 & 8.3 \\
\hline $16410-1$ & $08^{\circ} 54.6^{\prime}$ & $29^{\circ} 51.0^{\prime} \mathrm{W}$ & 3969 & 18.5 & 7.5 \\
\hline $16412-1$ & $09^{\circ} 33.6^{\prime}$ & $19^{\circ} 50.6^{\prime} \mathrm{W}$ & 4607 & no spike & \\
\hline $16413-1$ & $10^{\circ} 01.1^{\prime}$ & $19^{\circ} 18.2^{\prime} \mathrm{W}$ & 4397 & $\begin{array}{l}19.5 \\
41.0\end{array}$ & $\begin{array}{c}7.2 \\
13.5^{*}\end{array}$ \\
\hline 16415-1 & $09^{\circ} 34.0^{\prime}$ & $19^{\circ} 06.4^{\prime} \mathrm{W}$ & 3841 & 17.5 & 8.6 \\
\hline $16416-1$ & $09^{\circ} 51.9^{\prime}$ & $19^{\circ} 23.9^{\prime} \mathrm{W}$ & 4336 & $\begin{array}{l}23.5 \\
41.5\end{array}$ & $\begin{array}{c}9.1 \\
13.5^{*}\end{array}$ \\
\hline $16417-1$ & $10^{\circ} 04.1^{\prime}$ & $19^{\circ} 43.6^{\prime} \mathrm{W}$ & 4627 & 20.5 & 7.7 \\
\hline $16422-2$ & $09^{\circ} 14.3^{\prime}$ & $19^{\circ} 37.7^{\prime} \mathrm{W}$ & 4694 & no spike & \\
\hline $16424-1$ & $09^{\circ} 01.8^{\prime}$ & $19^{\circ} 20.1^{\prime} \mathrm{W}$ & 4648 & no spike & \\
\hline $16425-1$ & $09^{\circ} 08.2^{\prime}$ & $19^{\circ} 01.8^{\prime} \mathrm{W}$ & 4802 & no spike & \\
\hline $16426-1$ & $08^{\circ} 15.4^{\prime}$ & $18^{\circ} 26.0^{\prime} \mathrm{W}$ & 4766 & 16.0 & no age \\
\hline $16453-2$ & $04^{\circ} 44.0^{\prime}$ & $20^{\circ} 56.5^{\prime} \mathrm{W}$ & 2675 & $\begin{array}{c}8.5-11.0 \\
16.0\end{array}$ & $\begin{array}{c}6.7-8.0 \\
15.0\end{array}$ \\
\hline $16455-1$ & $05^{\circ} 16.2^{\prime}$ & $22^{\circ} 51.9^{\prime} \mathrm{W}$ & 4160 & $8.0-13.0$ & $4.7-7.2$ \\
\hline $16457-1$ & $05^{\circ} 23.5^{\prime}$ & $21^{\circ} 43.2^{\prime} \mathrm{W}$ & 3291 & $\begin{array}{c}8.7-13.5 \\
26.0\end{array}$ & $\begin{array}{c}4.7-7.5 \\
15.0\end{array}$ \\
\hline $16458-2$ & $05^{\circ} 20.1^{\prime}$ & $22^{\circ} 03.3^{\prime} \mathrm{W}$ & 3518 & $\begin{array}{c}11.0-12.2 \\
25.0\end{array}$ & $\begin{array}{c}7.7-8.3 \\
15.0\end{array}$ \\
\hline $23055-2$ & $68^{\circ} 25.4^{\prime}$ & $04^{\circ} 01.4^{\prime} \mathrm{E}$ & 2308 & 29.0 & 13.5 \\
\hline $23056-2$ & $68^{\circ} 30.1^{\prime}$ & $03^{\circ} 50.3^{\prime} \mathrm{E}$ & 2665 & 18.0 & $\sim 13.0$ \\
\hline $23057-1$ & $68^{\circ} 40.2^{\prime}$ & $03^{\circ} 30.1^{\prime} \mathrm{E}$ & 3157 & 19.5 & $\sim 13.5$ \\
\hline $23059-2$ & $70^{\circ} 18.3^{\prime}$ & $03^{\circ} 07.3^{\prime} \mathrm{W}$ & 2283 & 18.5 & 10.7 \\
\hline $23062-3$ & $68^{\circ} 43.0^{\prime}$ & $00^{\circ} 10.8^{\prime} \mathrm{E}$ & 2243 & 22.5 & 11.5 \\
\hline $23063-2$ & $68^{\circ} 44.8^{\prime}$ & $00^{\circ} 00.3^{\prime} \mathrm{E}$ & 2302 & 22.0 & $\sim 12.0$ \\
\hline $23064-2$ & $68^{\circ} 39.9^{\prime}$ & $00^{\circ} 19.4^{\prime} \mathrm{E}$ & 2571 & 18.0 & 10.2 \\
\hline $23065-2$ & $68^{\circ} 29.7$ & $00^{\circ} 49.9^{\prime} \mathrm{E}$ & 2804 & 17.0 & 11.5 \\
\hline 23068-3 & $67^{\circ} 50.0^{\prime}$ & $01^{\circ} 30.1^{\prime} \mathrm{E}$ & 2228 & 36.5 & 10.8 \\
\hline $23070-2$ & $67^{\circ} 20.4^{\prime}$ & $02^{\circ} 09.9^{\prime} \mathrm{E}$ & 1505 & $31.0-32.5$ & $\sim 8.5$ \\
\hline $23071-3$ & $67^{\circ} 05.1^{\prime}$ & $02^{\circ} 54.5^{\prime} \mathrm{E}$ & 1308 & $\begin{array}{l}51.5 \\
78.0\end{array}$ & $\begin{array}{r}9.5 \\
11.9\end{array}$ \\
\hline $23072-2$ & $67^{\circ} 00.0^{\prime}$ & $03^{\circ} 24.8^{\prime} \mathrm{E}$ & 1400 & $14.0-16.5$ & $\sim 9.8$ \\
\hline $23074-1$ & $66^{\circ} 40.0^{\prime}$ & $04^{\circ} 54.3^{\prime} \mathrm{E}$ & 1157 & $\begin{array}{l}102.0 \\
122.0\end{array}$ & $\begin{array}{r}8.5 \\
10.2\end{array}$ \\
\hline
\end{tabular}

* Poor age control because of widely spaced shear strength measurements.

sang, unpublished data, 1988]. Moreover, ${ }^{14} \mathrm{C}$ dates were measured on planktonic foraminifera coarser than $125 \mu \mathrm{m}$ at the C-14 Laboratory of Kiel University [Vogelsang, 1985; Sarnthein et al., 1988, unpublished data, 1988]. Age models for the last
12,000 to 27,000 years were generated for each box core containing sections up to $55 \mathrm{~cm}$ thick. The models are based on up to five ${ }^{14} \mathrm{C}$ dates for each core and/or various $\delta^{18} \mathrm{O}$ stratigraphic correlation points as defined below. In between we assumed 


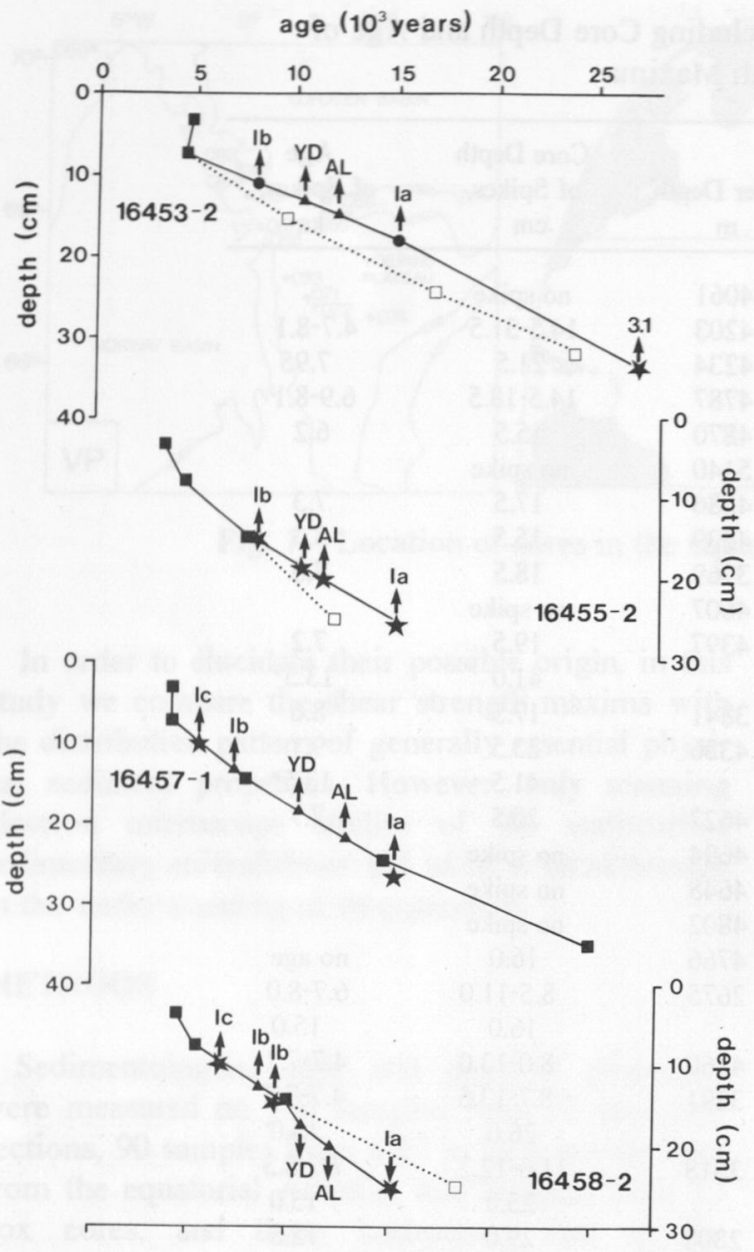

Fig. 2. Age-depth curves of sediment cores $16453-2,16455-2,16457-1$, and 16458-2 from the Sierra Leone Rise. Solid squares are datums derived from ${ }^{14} \mathrm{C}$ ages; open squares are rejected ${ }^{14} \mathrm{C}$ ages; Ia is the onset of Termination Ia at 15,000 years B.P.; $\mathrm{Ib}$ is the end of Termination $\mathrm{Ib}$ at $7000-8000$ years B.P.; Ic is the peak Holocene at $4700-6700$ years B.P.; YD is the Younger Dryas at 10,30010,700 years B.P.; AL is the Alleroed at 11,50012,300 years B.P.; solid circles are $\delta^{18} \mathrm{O}$ data from C. wuellerstorfi, asterisks are $\delta^{18} \mathrm{O}$ data from $G$. sacculifer, solid triangles are $\delta^{18} \mathrm{O}$ data from $G$. sacculifer and $C$. wuellerstorfi.

that the sedimentation rates were constant. Four of the "best dated" age-depth models from the equatorial Atlantic are depicted in Figure 2, and the respective $\delta^{18} \mathrm{O}$ curves in Figure 4. They are shown for cores where narrow-spaced data on the physical properties are also available.
The younger ${ }^{14} \mathrm{C}$ dates of cores 55,57 , and 58 match the $\delta^{18} \mathrm{O}$ correlation points along with glacial Termination I as defined by Duplessy et al. [1981] and Sarnthein et al. [1982] and largely confirmed by the recent accelerator mass spectrometry (AMS) datings of Duplessy et al. [1986], Bard et al. [1987], and Broecker et al. [1988] (Figure 2). According to these datings, which differ slightly from those from stacked $\delta^{18} \mathrm{O}$ curves of Mix and Ruddiman [1985], Termination IA started at about 15,000 years B.P. and reached the first pronounced warm phase 11,500-12,250 years ago. The Younger Dryas cooling occurred 10,700-10,300 years ago, and the subsequent Termination IB ended about 8000 years ago, although the different AMS-dated core sections indicate a wide age range between 9300 and 7300 years B.P.. In the data set of cores 55,57 , and 58 the end of Termination IB is indeed ${ }^{14} \mathrm{C}$-dated at $7600-8900$ years B.P. in the planktonic $\delta^{18} \mathrm{O}$ records and at $7100-7900$ years B.P. in the benthic records. In most of our benthic and planktonic records, except for core 57 , however, the onset age of Termination IA near 15,000 years B.P. strongly disagrees with our ${ }^{14} \mathrm{C}$ dates but is well confirmed by constant sedimentation rates in relation to the other "established" correlation points of the curves at the Alleröd warm peak $(12,400-11,500$ years B.P.) and the Younger Dryas (10,700-10,400 years B.P.). Hence we discarded most ${ }^{14} \mathrm{C}$ dates older than 10,000 years, probably because of lateral sediment winnowing and advection at the slope of the Sierra Leone Rise. This holds particularly true for core 53 from the top of Sierra Leone Rise. Except for two "modern" ages, all ${ }^{14} \mathrm{C}$ datings of this core appear markedly too young, by $3000-4000$ years as compared to the $\delta^{18} \mathrm{O}$ correlation points. Also we relate this shift to persistent winnowing of old sediment at this exposed core location with low sedimentation rates.

On the base of the age-depth curves of all four cores in Figure 2 the modern bioturbational mixing depth is fairly well defined with a thickness of $5.0-7.5 \mathrm{~cm}$, equivalent to $3500-4500$ years. Furthermore, the Holocene planktonic $\delta^{18} \mathrm{O}$ minima, which range from -1.20 to $-1.24 \%$, can be dated at 4400-5300 years B.P., an age that comes close to the end of Termination IC as defined by Mix and Ruddiman [1985] at 6000 years B.P..

A dating precision similar to that of cores $53-58$ was established for cores $02,03,07$, and 15 in the equatorial Atlantic and cores 055, 059, 062, and 065 in the Norwegian Sea. The stratigraphy of 

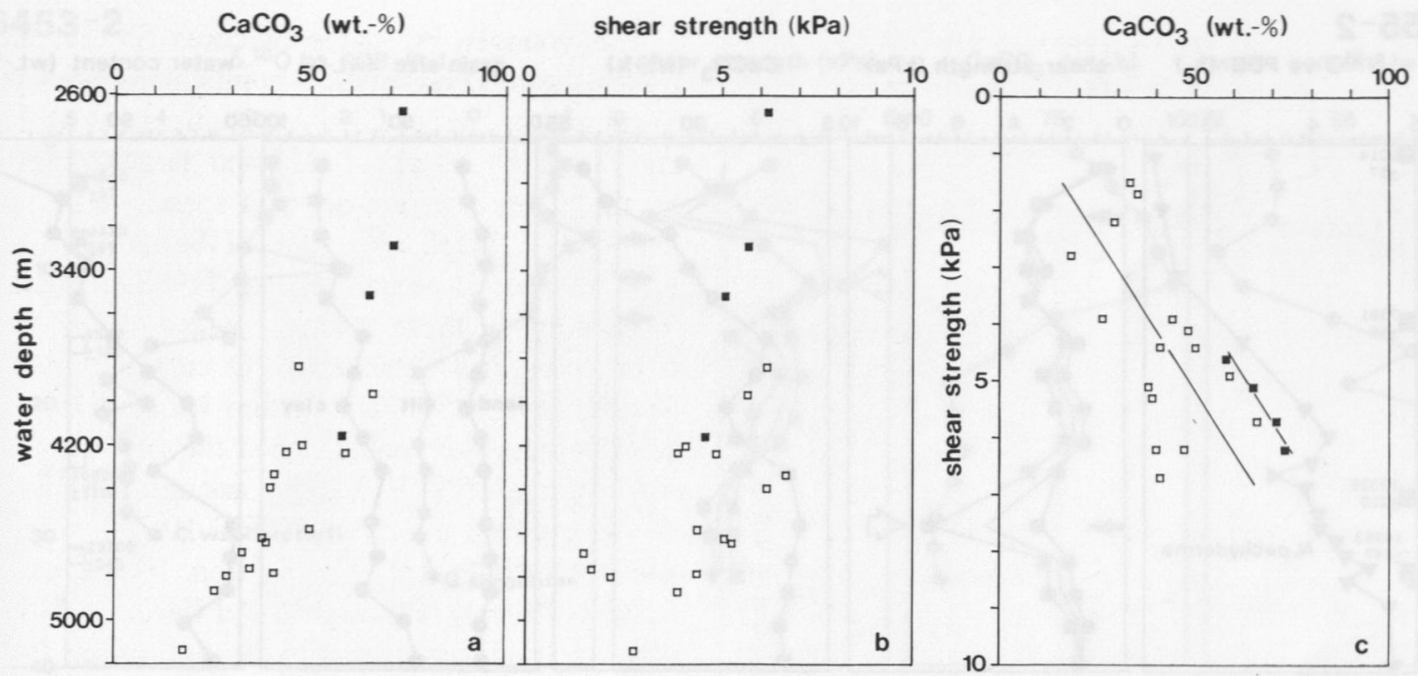

Fig. 3. (a) Percent $\mathrm{CaCO}_{3}$ of surface sediments versus water depth, (b) undrained shear strength in surface sediments of the equatorial Atlantic versus water depth, (c) shear strength of surface sediments versus percent $\mathrm{CaCO}_{3}$. Note equal gradients of regression lines for average values from both high- and low-resolution measurements. In Figures $3 a-3 c$ each datum presents an average value of the topmost $30-\mathrm{cm}$ sediment profile, with solid squares from high-resolution profiles, and open squares from low-resolution profiles.

cores $01,04,05,06,08,10,12,13,16,17,22,24$, $25,26,056,057,063,064,068,069,070,071,072$ and 074 is based on less than three to four ${ }^{14} \mathrm{C}$ ages and, for the most part, only on a less highly resolving planktonic oxygen isotope record.

\section{RESULTS}

\section{Regional Distribution Pattern of Undrained Shear Strength}

As first demonstrated by Berger and Johnson [1976] and Johnson et al. [1977], average undrained shear strengths vary with the water depth in pelagic carbonate sediments. Shear strengths behave similarly in the surface sediments, i.e., the clayey foraminifera-nannofossil oozes of the equatorial east Atlantic where they decline from an average of 6 kilopascal $(\mathrm{kPa})$ to $2 \mathrm{kPa}$ from 2675 to $5140 \mathrm{~m}$ water depth (Figures $3 \mathrm{a}$ and $3 \mathrm{~b}$ ). This difference value matches the one reported from the Ontong Java Plateau in the west Pacific [Johnson et al., 1977] and parallels a decrease in the $\mathrm{CaCO}_{3}$ content of the sediments in both regions. On the average, a decrease in shear strength by $1 \mathrm{kPa}$ corresponds to a $9.3 \%$ (absolute) reduction of the carbonate content (Figure $3 \mathrm{c}$ ). This parallel equally applies to both high- and low-resolution data and may provide a key to understanding the origin of the downslope decrease in shear strength.

Since the carbonate content of pelagic sediments in general closely correlates with the abundance of the coarse fraction greater than $63 \mu \mathrm{m}$ [Cita and Spezzibottiani, 1979] the relationship between percent $\mathrm{CaCO}_{3}$ and shear strength may actually derive from the grain size distribution pattern. On the other hand, Berger and Johnson [1976], suggested as early as 1976 that processes of early diagenetic cementation may primarily cause the link between percent $\mathrm{CaCO}_{3}$ and shear strength. In the lowlatitude east Atlantic the decrease in shear strength is most pronounced slightly above $4000 \mathrm{~m}$ water depth, i.e., near the average depth of the lysocline [Berger, 1978; Thunell, 1982].

\section{Downcore Variations of Undrained Shear Strength}

In sediment cores from the equatorial east Atlantic at 2500-5000 m water depth (cores 02-05, $07,08,10,12,13,15-17,24,53,55,57$, and 58 [Kassens, 1985] all pelagic, hemipelagic, nonturbiditic, and not-current-swept profiles exhibit a first pronounced maximum of undrained shear strength at about $10-20 \mathrm{~cm}$ below the sediment surface. A similar pattern of indurated sediment beds, the shear strength of which gradually weakens 


\section{5-2}

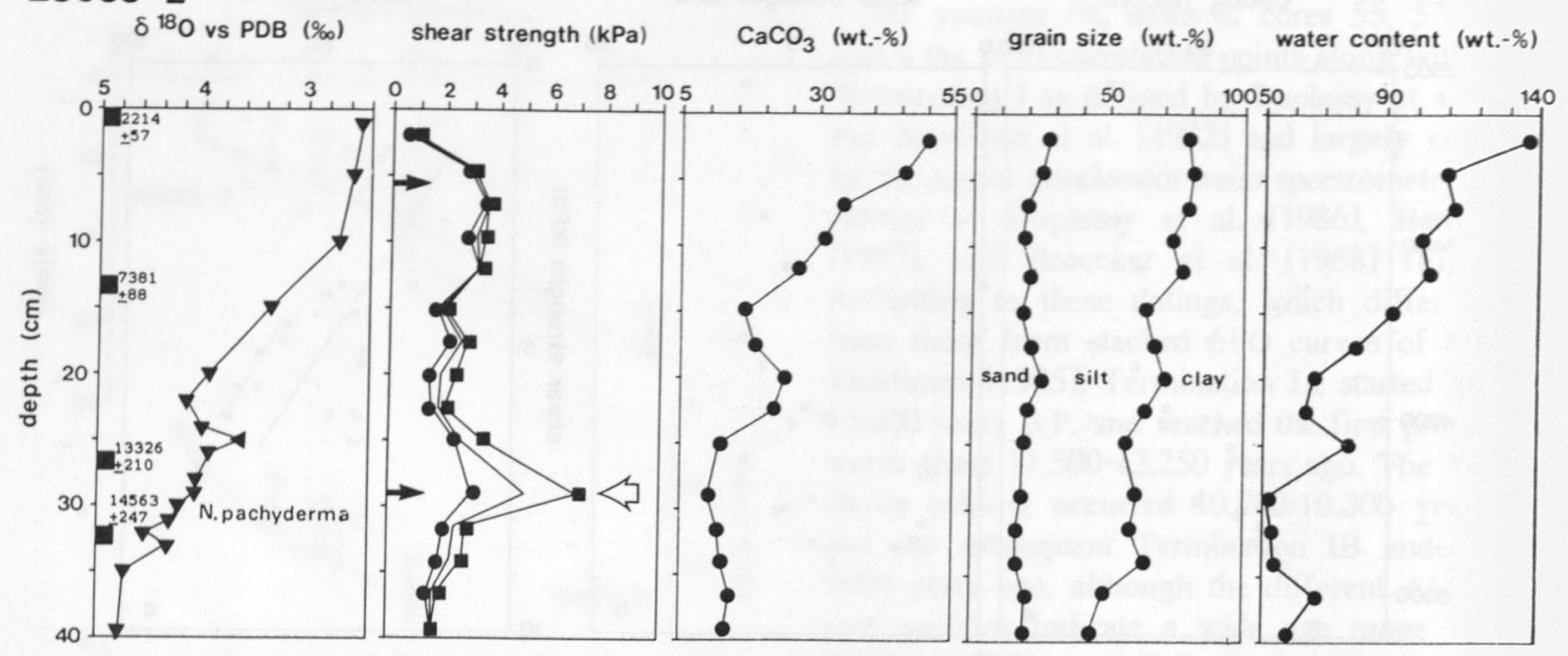

23059-2

$\delta{ }^{18} \mathrm{O}$ vs PDB $(\%) \quad$ shear strength $(\mathrm{kPa}) \quad \mathrm{CaCO}_{3}(w t . \%) \quad$ grain size (wt. $\left.\%\right) \quad$ water content (wt. $\left.\%\right)$

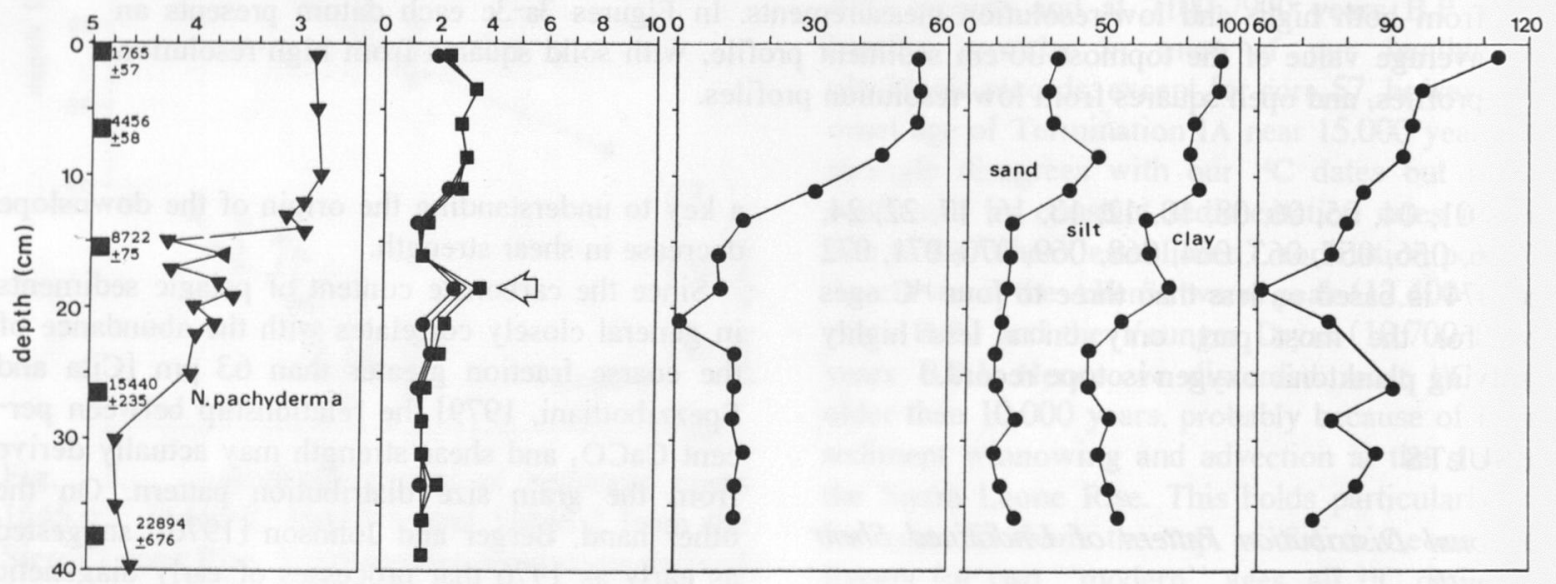

Fig. 4a.

Fig. 4. Examples of (maximum, mean, and minimum) shear strength profiles (in kilopascals) as compared with $\delta^{18} \mathrm{O}$ stratigraphy of $G$. sacculifer and $C$. wuellerstorfi or $N$. pachyderma, $\mathrm{CaCO}_{3}$ concentrations, and water content in the sediment. Solid squares are accepted ${ }^{14} \mathrm{C}$ ages; open squares are ${ }^{14} \mathrm{C}$ ages rejected for chronostratigraphy (see Figure 2). Mean shear strength values are based on three to five measurements each at the same depth level. Solid arrows indicate the position of samples for the stereoscan microscope. Grain sizes are plotted for profiles from the Norwegian Sea (core 23055-2 and 23059-2). Shear strength maxima marked by open arrows. For further physical sediment properties see Table 2 .

from SE to NW, occurs at $17-102 \mathrm{~cm}$ depth in core profiles from the Norwegian Sea (cores 055-057, 059, 062-065, 068, 070- 072, and 074; two examples are depicted in Figure 4a). As demonstrated by four sediment sections from the southwestern Sierra Leone Rise (Figure $4 b$ and $4 c$ ), shear strengths may increase from $1.2 / 6.6 \mathrm{kPa}$ near the sediment surface up to $9.2 / 11.8 \mathrm{kPa}$ at $8-11 \mathrm{~cm}$ depth (e.g., core 53). Further below, they drop back to $4.5 / 7.0 \mathrm{kPa}$ at $13 \mathrm{~cm}$ depth and remain about constant down to $35 \mathrm{~cm}$. Moreover, a few cores from the equatorial Atlantic (e.g., 57 and 58) show a bipartite maximum with a second peak at 16-41 $\mathrm{cm}$ depth (Figure 4). A few similar near-surface 
$16453-2$
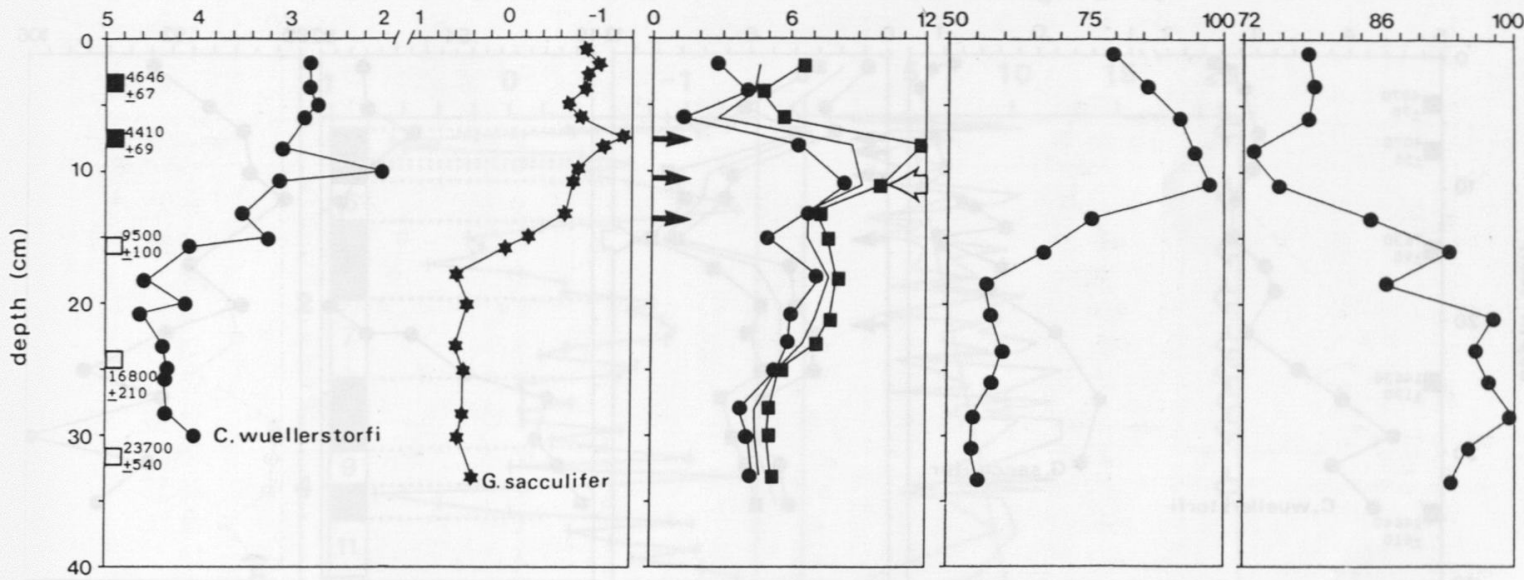

16455-2

$\delta{ }^{18} \mathrm{O}$ vs PDB $(\%) \quad$ shear strength $(\mathrm{kPa})$

$\mathrm{CaCO}_{3}$ (wt.-\%) water content (wt.-\%)
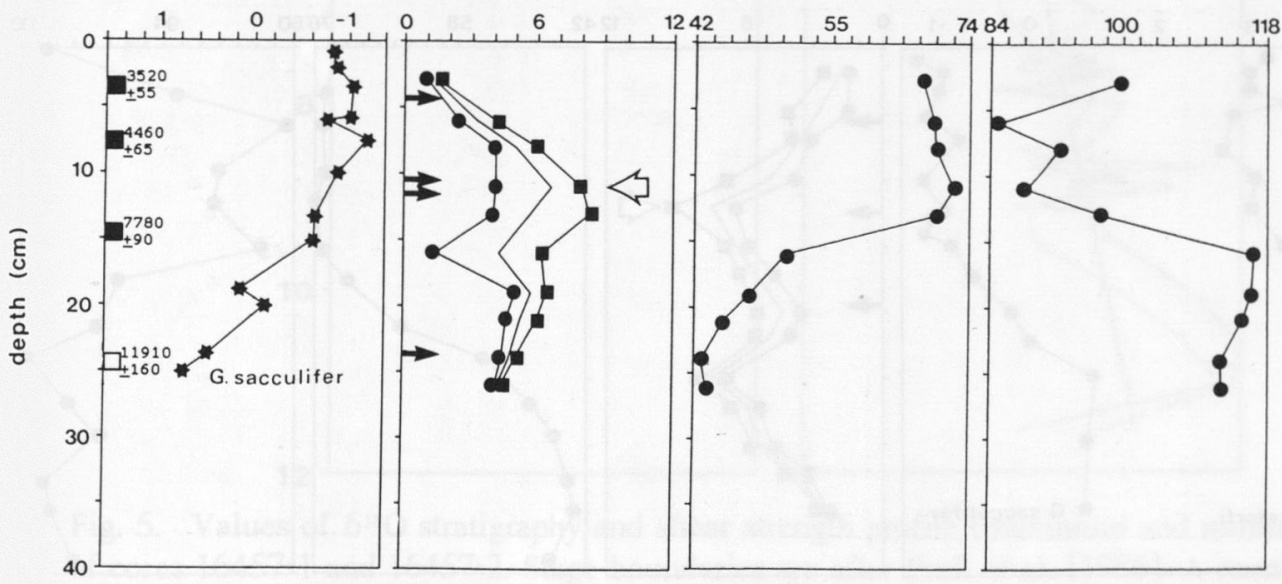

Fig. 4b.

indurated beds were reported from other parts of the ocean, for example, from pelagic sediments in the Arabian Sea [Kögler, 1967], the Red Sea, and the Gulf of Aden [Einsele and Werner, 1968].

Normal, undisturbed pelagic sediment sections strongly differ in their shear strength distribution from profiles obtained from regions, which are swept by bottom currents such as the Kane Gap [Sarnthein et al., 1985; Mienert, 1986] (cores 22, and 24-25). In these depositional environments indurated layers are absent and the undrained shear strength stays constant or gradually declines from about $2.0 / 5.3 \mathrm{kPa}$ near the surface to $0.9 / 1.0 \mathrm{kPa}$ below $30 \mathrm{~cm}$ depth, probably because of the dominant influence of the grain size distribution.
The same holds true for near-surface turbidites where shear strengths gradually decrease downcore (core 6) or increase (core 1) [Kassens, 1985]. On the base of oxygen isotope stratigraphy and ${ }^{14} \mathrm{C}$ dates [Vogelsang, 1985] all near-surface indurated beds in pelagic sediments from the low-latitudinal Atlantic show about the same age centered after glacial Termination I, just below the Holocene climatic optimum, $7000 \pm 1000$ years B.P. (Figure 4 , Table 1). The occasionally observed second shear strength maximum dates at about 15,000 years B.P., i.e., the layers may be linked to (a pair of) single rare events of environmental forcing. The scatter in the dating mainly derives from vertical distances of shear strength data that are two great during the 
$16457-1$

$\delta{ }^{18} \mathrm{O}$ vs PDB $(\%)$

shear strength $(\mathrm{KPa})$

$\mathrm{CaCO}_{3}($ wt.- $\%)$

water content (wt. $\%$ )
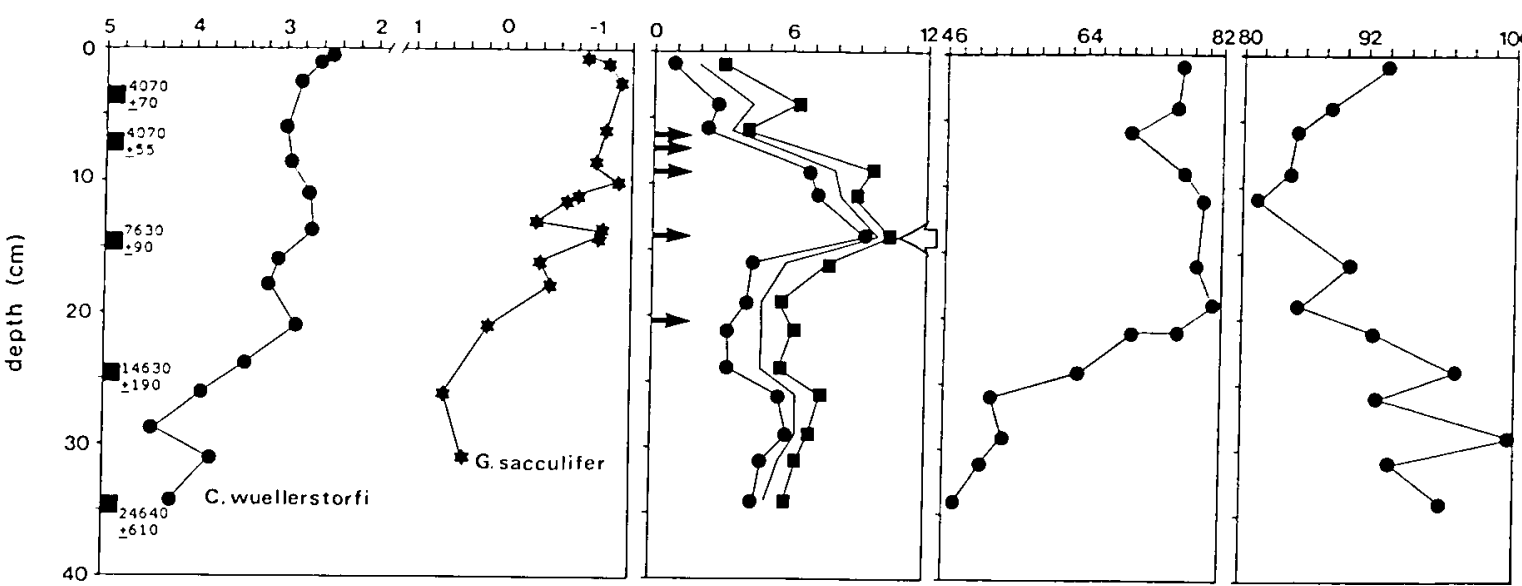

16458-2

$\delta{ }^{18} \mathrm{O}$ vs $\mathrm{PDB}(\%)$

shear strength $(\mathrm{kPa})$

$\mathrm{CaCO}_{3}$ (wt.-\%) water content (wt.-\%)
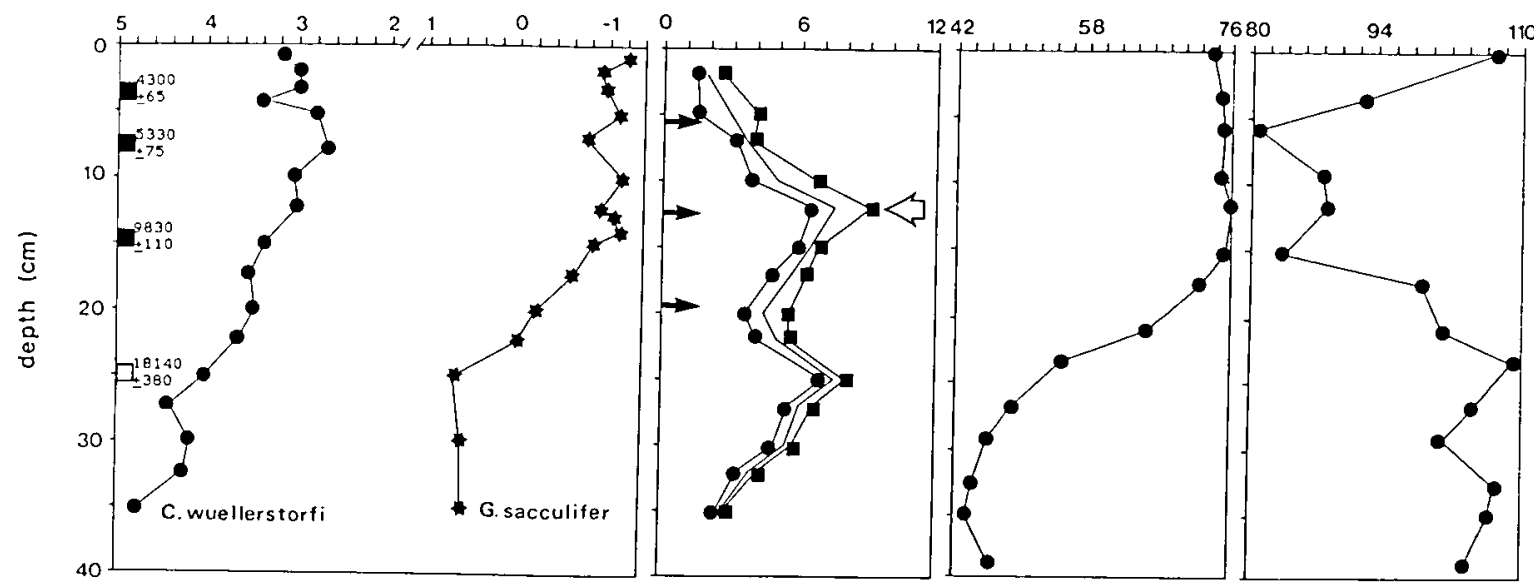

Fig. 4c.

early phase of our study (see Table 1). On the other hand, the shear strength maxima of the Norwegian Sea appear to be much older and time transgressive from 13,500 to 8500 years B.P., essentially from north to south.

An investigation of a long core section of pelagic foraminifera-nannofossil ooze with modest sedimentation rates of about $1.25 \mathrm{~cm}$ per 1000 years from the southwest Sierra Leone Rise (gravity core 57) revealed numerous additional short-term spikes of shear strength farther downcore, with amplitudes similar to those during the mid-Holocene (Figure 5). The sequence of spikes does not follow a simple scheme. Many of them (four) are linked to early peak interglacial events, with two spikes linked to warm events during cold Quaternary stages. Four maxima parallel phases of rapid climatic deterioration as depicted in the $\delta^{18} \mathrm{O}$ record. All spikes are superimposed on an overall continuous downcore increase in average shear strength amounting to $0.94 \mathrm{kPa}$ per meter of depth, whereas the long-term range of $\mathrm{CaCO}_{3}$ variations remains basically constant between 30 and $75 \%$. This long-term rise in shear strength at basically constant $\mathrm{CaCO}_{3}$ concentrations corresponds to the general trend proposed by Richards [1962] for normally consolidating marine sediments and is proportional to increasing wet bulk density and 


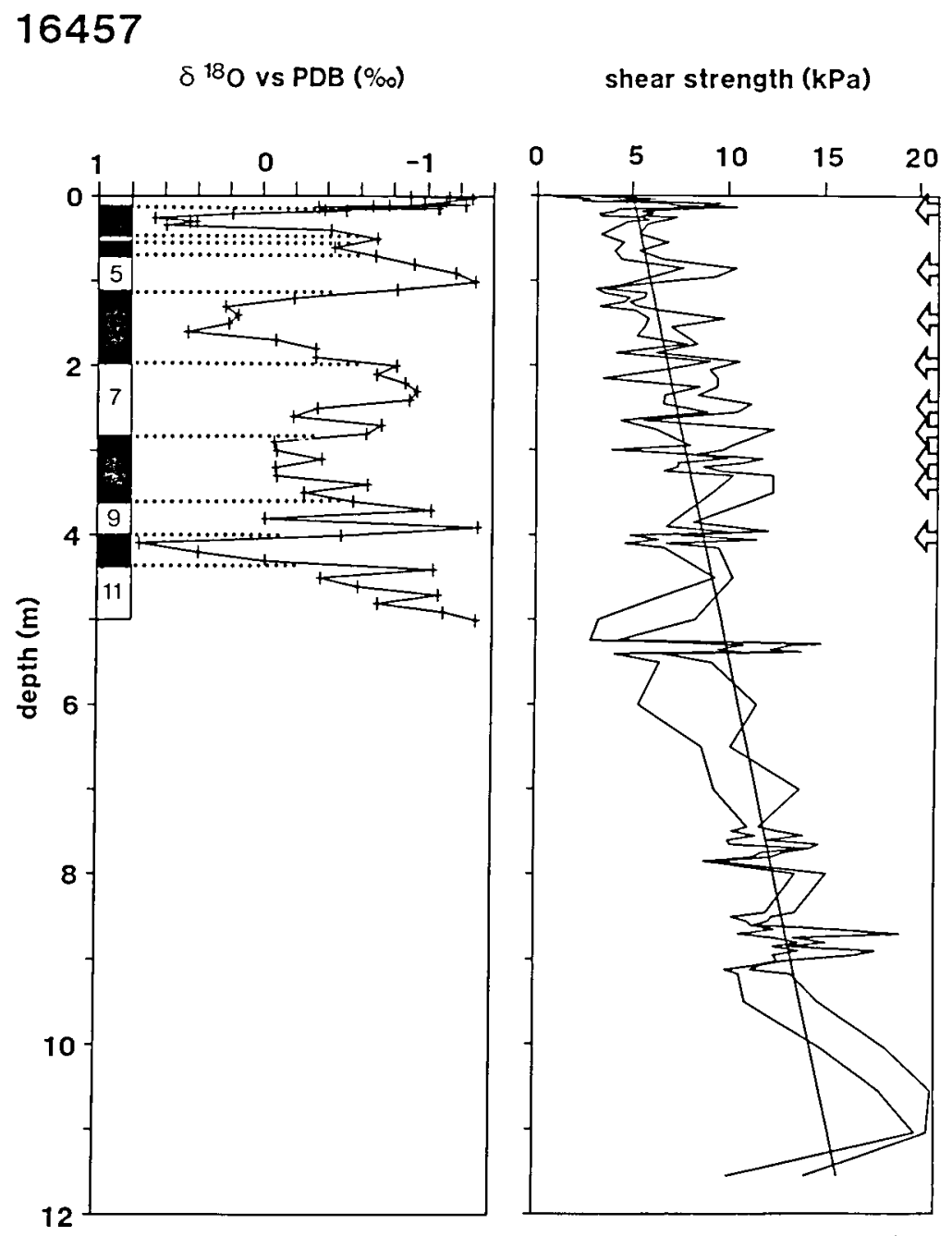

Fig. 5. Values of $\delta^{18} \mathrm{O}$ stratigraphy and shear strength profile (maximum and minimum values) of cores 16457-1 and 16457-2. Stage boundaries are after Prell et al. [1986]. A number of shear strength spikes are superimposed on a continuous gradual downcore increase in shear strength by $0.94 \mathrm{kPa}$ per meter of sediment depth. Shear strength maxima (open arrows) lie at early peak interglacial stages 1, 7.3, 7.5, 9.3; at warm substages 6.3, 8.3, 8.5; and at phases of the most rapid climatic deterioration at the stage $7 / 6$ boundary and late stage 5.5 .

decreasing water content and porosity. The nearsurface and deeper shear strength spikes, however, require a different explanation.

\section{ORIGIN OF SHEAR STRENGTH SPIKES}

\section{The Role of Conventional Sediment Properties}

The striking near-surface maxima in undrained shear strength mostly occur near the base of the general $\mathrm{CaCO}_{3}$ maximum in Holocene sediments or as much as $13 \mathrm{~cm}$ below, but rarely above (Figure 4). According to Figure $3 \mathrm{c}$ a reduction in the pelagic $\mathrm{CaCO}_{3}$ content by $10 \%$ induces a decline in shear strength by about $1.1 \mathrm{kPa}$. Hence, the pre-Holocene decrease in percent $\mathrm{CaCO}_{3}$ might explain part of the observed decrease in shear strength downcore from the maximum, up to 4.5 $\mathrm{kPa}$. In most cases, however, especially at water depths of more than $3300 \mathrm{~m}$, the reduction in $\mathrm{CaCO}_{3}$ and the decrease in shear strength do not directly overlap. Thus $\mathrm{CaCO}_{3}$ cannot explain the 
TABLE 2. Sediment Variables of Cores 16453-2, 16455-1, 16457-1, 16458-2. 23055-2, and 23059-2

\begin{tabular}{|c|c|c|c|c|c|c|c|c|}
\hline Core & $\begin{array}{c}\text { Depth, } \\
\mathrm{cm}\end{array}$ & $\begin{array}{l}\text { Sand, } \\
\text { wt \% }\end{array}$ & $\begin{array}{l}\text { Silt, } \\
\text { wt \% }\end{array}$ & $\begin{array}{l}\text { Clay, } \\
\text { wt \% }\end{array}$ & $\begin{array}{c}\text { Organic } \\
\text { Carbon, } \\
\text { wt } \%\end{array}$ & $\begin{array}{l}\text { Wet Bulk } \\
\text { Density, } \\
\mathrm{g} / \mathrm{cm}^{3}\end{array}$ & $\begin{array}{c}\text { Overburden } \\
\text { Pressure, } \\
\text { kPa }\end{array}$ & Sensitivity \\
\hline \multirow[t]{14}{*}{$16453-2$} & 1.00 & 44.86 & 24.26 & 30.88 & 0.50 & 1.45 & 0.11 & 38.42 \\
\hline & 3.50 & 47.22 & 32.72 & 20.06 & 0.49 & 1.48 & 0.23 & 19.04 \\
\hline & 6.00 & 55.42 & 21.84 & 22.74 & 0.43 & 1.43 & 0.33 & 39.86 \\
\hline & 8.50 & 49.27 & 23.84 & 26.89 & 0.34 & 1.42 & 0.44 & 51.35 \\
\hline & 11.00 & 51.20 & 24.40 & 24.40 & 0.27 & 1.49 & 0.56 & 43.71 \\
\hline & 13.50 & 47.06 & 18.53 & 34.41 & 0.28 & 1.45 & 0.67 & 61.73 \\
\hline & 16.00 & 33.30 & 24.68 & 42.02 & 0.36 & 1.49 & 0.79 & 45.07 \\
\hline & 18.50 & 25.49 & 33.16 & 41.35 & 0.36 & 1.34 & 0.87 & 35.05 \\
\hline & 21.00 & 27.46 & 26.84 & 45.70 & 0.30 & 1.54 & 1.00 & 35.55 \\
\hline & 23.50 & 30.96 & 24.85 & 44.19 & 0.37 & 1.40 & 1.10 & 41.00 \\
\hline & 26.00 & 32.12 & 26.13 & 41.75 & 0.36 & 1.45 & 1.21 & 36.27 \\
\hline & 28.50 & 28.04 & 24.11 & 47.85 & 0.40 & 1.45 & 1.32 & 34.23 \\
\hline & 31.00 & 30.46 & 26.77 & 42.77 & 0.39 & 1.43 & 1.43 & 29.93 \\
\hline & 33.50 & 32.84 & 22.17 & 44.99 & 0.38 & 1.42 & 1.53 & 33.50 \\
\hline \multirow[t]{10}{*}{$16455-1$} & 3.00 & 33.60 & 26.56 & 39.84 & 0.60 & 1.46 & 0.09 & 15.11 \\
\hline & 6.00 & 35.97 & 25.53 & 38.50 & 0.59 & 1.35 & 0.18 & 26.92 \\
\hline & 8.00 & 34.82 & 27.38 & 37.80 & 0.53 & 1.45 & 0.29 & 26.47 \\
\hline & 11.00 & 34.35 & 28.34 & 37.31 & 0.45 & 1.45 & 0.40 & 41.63 \\
\hline & 13.00 & 34.49 & 24.74 & 40.77 & 0.37 & 1.36 & 0.49 & 30.05 \\
\hline & 16.00 & 17.02 & 33.19 & 49.79 & 0.28 & 1.42 & 0.59 & 32.69 \\
\hline & 19.00 & 11.92 & 35.23 & 52.85 & 0.25 & 1.37 & 0.68 & 31.89 \\
\hline & 21.00 & 9.53 & 38.90 & 51.57 & 0.25 & 1.35 & 0.77 & 32.88 \\
\hline & 24.00 & 8.41 & 39.38 & 52.21 & 0.24 & 1.34 & 0.85 & 36.31 \\
\hline & 26.00 & 8.75 & 32.85 & 58.40 & 0.24 & 1.33 & 0.93 & 46.78 \\
\hline \multirow[t]{14}{*}{$16457-1$} & 1.00 & 52.11 & 25.38 & 26.61 & 0.58 & 1.50 & 0.12 & 21.78 \\
\hline & 4.00 & 50.72 & 22.67 & 22.51 & 0.56 & 1.55 & 0.26 & 61.14 \\
\hline & 6.00 & 53.08 & 24.87 & 22.05 & 0.47 & 1.47 & 0.37 & 33.70 \\
\hline & 9.00 & 53.13 & 24.84 & 22.03 & 0.42 & 1.49 & 0.49 & 65.92 \\
\hline & 11.00 & 53.09 & 24.39 & 22.52 & 0.31 & 1.42 & 0.59 & 81.90 \\
\hline & 16.00 & 52.28 & 23.38 & 24.34 & 0.32 & 1.63 & 0.75 & 98.40 \\
\hline & 19.00 & 54.97 & 22.06 & 22.97 & 0.24 & 1.48 & 0.87 & 115.80 \\
\hline & 21.00 & 48.92 & 21.45 & 29.63 & 0.27 & 1.54 & 1.00 & 94.60 \\
\hline & 22.00 & 42.73 & 22.34 & 34.93 & 0.30 & 1.42 & 1.10 & 95.40 \\
\hline & 24.00 & 34.59 & 31.72 & 33.69 & 0.34 & 1.49 & 1.22 & 52.44 \\
\hline & 26.00 & 25.66 & 23.42 & 50.92 & 0.36 & 1.41 & 1.32 & 57.09 \\
\hline & 29.00 & 28.52 & 26.99 & 44.49 & 0.26 & 1.48 & 1.44 & 52.42 \\
\hline & 31.00 & 25.79 & 23.38 & 50.83 & 0.29 & 1.39 & 1.53 & 55.40 \\
\hline & 34.00 & 24.16 & 30.34 & 45.50 & 0.28 & 1.47 & 1.65 & 45.09 \\
\hline \multirow[t]{11}{*}{$16458-2$} & 2.00 & 47.32 & 22.65 & 30.03 & 0.54 & 1.46 & 0.11 & 23.00 \\
\hline & 5.00 & 51.69 & 23.19 & 25.12 & 0.49 & 1.51 & 0.24 & 24.00 \\
\hline & 7.00 & 47.53 & 25.19 & 27.28 & 0.44 & 1.52 & 0.36 & 27.69 \\
\hline & 10.00 & 47.88 & 24.47 & 27.65 & 0.37 & 1.44 & 0.47 & 41.58 \\
\hline & 12.00 & 43.18 & 25.00 & 31.82 & 0.32 & 1.49 & 0.59 & 62.58 \\
\hline & 15.00 & 43.41 & 23.77 & 32.82 & 0.30 & 1.52 & 0.72 & 49.62 \\
\hline & 17.00 & 41.03 & 27.13 & 31.84 & 0.25 & 1.50 & 0.84 & 94.00 \\
\hline & 20.00 & 33.96 & 30.38 & 35.66 & 0.24 & 1.37 & 0.93 & 48.67 \\
\hline & 22.00 & 21.87 & 31.10 & 47.03 & 0.25 & 1.42 & 1.03 & 38.46 \\
\hline & 25.00 & 19.86 & 28.85 & 51.29 & 0.28 & 1.40 & 1.13 & 37.65 \\
\hline & 27.00 & 18.95 & 23.94 & 55.11 & 0.29 & 1.38 & 1.23 & 30.05 \\
\hline
\end{tabular}


TABLE 2. (continued)

\begin{tabular}{|c|c|c|c|c|c|c|c|c|}
\hline Core & $\begin{array}{l}\text { Depth, } \\
\text { cm }\end{array}$ & $\begin{array}{l}\text { Sand, } \\
\text { wt \% }\end{array}$ & $\begin{array}{l}\text { Silt, } \\
\text { wt \% }\end{array}$ & $\begin{array}{l}\text { Clay, } \\
\text { wt } \%\end{array}$ & $\begin{array}{c}\text { Organic } \\
\text { Carbon, } \\
\text { wt \% }\end{array}$ & $\begin{array}{l}\text { Wet Bulk } \\
\text { Density, } \\
\mathrm{g} / \mathrm{cm}^{3}\end{array}$ & $\begin{array}{c}\text { Overburden } \\
\text { Pressure, } \\
\text { kPa }\end{array}$ & Sensitivity \\
\hline \multirow[t]{3}{*}{$16458-2$} & 30.00 & 15.20 & 37.31 & 47.49 & 0.29 & 1.34 & 1.31 & 38.57 \\
\hline & 32.00 & 17.16 & 31.48 & 51.36 & 0.28 & 1.44 & 1.42 & 22.71 \\
\hline & 35.00 & 23.20 & 27.65 & 49.15 & 0.28 & 1.41 & 1.52 & 20.38 \\
\hline \multirow[t]{15}{*}{$23055-2$} & 2.00 & 27.87 & 51.53 & 20.60 & 0.58 & 1.25 & 0.05 & 4.44 \\
\hline & 4.50 & 25.02 & 55.78 & 19.20 & 0.44 & 1.29 & 0.12 & 9.38 \\
\hline & 7.00 & 19.62 & 59.78 & 20.60 & 0.45 & 1.38 & 0.21 & 9.47 \\
\hline & 9.50 & 18.03 & 54.97 & 27.00 & 0.43 & 1.34 & 0.29 & 9.29 \\
\hline & 12.00 & 21.61 & 54.99 & 23.40 & 0.38 & 1.30 & 0.36 & 9.31 \\
\hline & 15.00 & 18.14 & 45.66 & 36.20 & 0.36 & 1.31 & 0.46 & 6.13 \\
\hline & 17.50 & 21.14 & 45.66 & 33.20 & 0.38 & 1.36 & 0.55 & 6.79 \\
\hline & 20.00 & 25.77 & 44.83 & 29.40 & 0.21 & 1.42 & 0.65 & 4.68 \\
\hline & 22.50 & 19.93 & 43.67 & 36.40 & 0.25 & 1.57 & 0.79 & 3.44 \\
\hline & 25.00 & 18.95 & 37.05 & 44.00 & 0.30 & 1.34 & 0.88 & 5.06 \\
\hline & 29.00 & 18.43 & 42.37 & 39.20 & 0.35 & 1.50 & 1.07 & 5.32 \\
\hline & 31.50 & 16.67 & 41.93 & 41.40 & 0.22 & 1.48 & 1.19 & 3.10 \\
\hline & 34.00 & 16.74 & 46.66 & 36.60 & 0.20 & 1.65 & 1.35 & 3.19 \\
\hline & 36.50 & 20.20 & 28.20 & 51.60 & 0.23 & 1.46 & 1.47 & 2.23 \\
\hline & 39.50 & 19.57 & 23.83 & 56.60 & 0.23 & 1.52 & 1.62 & 2.63 \\
\hline \multirow[t]{15}{*}{$23059-2$} & 1.00 & 33.15 & 60.05 & 6.80 & 0.67 & 1.41 & 0.04 & 4.98 \\
\hline & 3.50 & 28.94 & 63.06 & 8.00 & 0.48 & 1.48 & 0.16 & 6.22 \\
\hline & 6.00 & 31.19 & 52.01 & 16.80 & 0.40 & 1.49 & 0.28 & 4.51 \\
\hline & 8.50 & 47.35 & 33.85 & 18.80 & 0.34 & 1.48 & 0.40 & 4.70 \\
\hline & 11.00 & 37.53 & 47.47 & 15.00 & 0.27 & 1.52 & 0.52 & 4.81 \\
\hline & 13.50 & 16.20 & 48.60 & 35.20 & 0.24 & 1.53 & 0.65 & 2.55 \\
\hline & 16.00 & 16.12 & 50.88 & 33.00 & 0.28 & 1.59 & 0.80 & 2.25 \\
\hline & 18.50 & 15.02 & 59.18 & 25.80 & 0.28 & 1.65 & 0.96 & 4.01 \\
\hline & 21.00 & 13.14 & 43.26 & 43.60 & & 1.54 & 1.09 & 2.66 \\
\hline & 23.50 & 10.53 & 33.87 & 55.60 & 0.26 & & & \\
\hline & 26.00 & 10.53 & 33.87 & 55.60 & 0.31 & 1.44 & 1.31 & 2.28 \\
\hline & 28.50 & 17.92 & 34.28 & 47.80 & 0.30 & 1.54 & 1.44 & 2.31 \\
\hline & 31.00 & 9.36 & 38.84 & 51.80 & 0.25 & 1.52 & 1.57 & 2.47 \\
\hline & 33.50 & 12.32 & 39.08 & 48.60 & 0.30 & 1.54 & 1.70 & 2.64 \\
\hline & 36.00 & 17.54 & 37.46 & 45.00 & 0.37 & 1.57 & 1.84 & 2.42 \\
\hline
\end{tabular}

shear strength decrease of up to $5 \mathrm{kPa}$. Furthermore, the $\mathrm{CaCO}_{3}$-shear strength relationship cannot explain either the marked mid-Holocene downcore increase in shear strength at constant $\mathrm{CaCO}_{3}$ concentrations or the occasional second shear strength spike found downcore within a carbonate minimum (Figure 4, cores 57 and 58). Finally, the carbonate stratigraphy appears to be time transgressive across different water depths, whereas the shear strength spike is fairly synchronous within the equatorial Atlantic. In summary, the whole group of conventional sediment properties related to percent $\mathrm{CaCO}_{3}$ variations such as grain size, wet bulk density, porosity, grain density, and remolded shear strength apparently has little bearing on the formation of the near-surface maxima in shear strength in foraminiferal nannofossil-ooze.

In particular, the effective overburden pressure, which rises continuously downcore in all profiles (Table 2), is unrelated to the shear strength maxima. By theory they correspond to much higher pressure values $(35-40 \mathrm{kPa}$ instead of only the 4-6 $\mathrm{kPa}$ observed) and hence record "overconsolidation."

Models that employ phases of erosion and slumping in order to explain the abrupt increases in shear strength by overconsolidation [Einsele and Werner, 1968; Bjerrum, 1973; Almagor and Wiseman, 1977; Holler, 1988] do not apply to our 
observed shear strength maxima. For example, the well-known stratigraphic record of most of our pelagic sediment profiles excludes any erosional hiatuses and layers of slumped sediment and demonstrates continuous deposition $\left(\delta^{18} \mathrm{O}\right.$ curves in Figures 4 and 5). Accordingly, the great overconsolidation expected for the near-surface spikes in shear strength must be regarded as "apparent" (sensu Richards and Hamilton [1967]). To some degree this feature appears as a general characteristic of sediments in the deep sea [Einsele, 1982]. Various authors already considered early cementation phases as a potential cause [Kögler, 1967; Einsele and Werner, 1968; Richards and Hamilton, 1967; Wise, 1977]. New evidence for this model is presented in the following section.

\section{Cementation Fabrics}

We studied a number of undisturbed sediment samples from the equatorial Atlantic and the Norwegian Sea (box cores 02, 15, 53, 55, 57, 58, and 055 ) under the stereoscan electron microscope in order to investigate the pore fabrics and their fillings. The walls of numerous microvugs were covered with crusts of micritic carbonate and silicate and authigenic crystal carpets (Figure 6). This cementation is clearly restricted to the shear strength maximum and does not occur above or below it. By means of microprobe and EDAX analyses the authigenic minerals from the equatorial Atlantic were identified as calcite, in part with zonal lamination, and aragonite. Carpets of $\mathrm{SiO}_{2}$ needles occur in samples more proximal to northwest Africa. Needles of an as yet unidentified $\mathrm{K},-\mathrm{Mg},-\mathrm{Fe},-\mathrm{Al}$ silicate $\left(\mathrm{K}_{2} \mathrm{O}: 7.1 \%\right.$; $\mathrm{CaO}: 1.9 \%$; $\mathrm{MgO}: 10.9 \%$; $\mathrm{FeO}: 16.1 \% ; \mathrm{Al}_{2} \mathrm{O}_{3}: 19.3 \%$; $\mathrm{TiO}_{2}$ : $\left.2.2 \% ; \mathrm{SiO}_{2}: 41.7 \%\right)$ are present in core $2(25-26 \mathrm{~cm}$ depth), although their coincidence with $\mathrm{CaCO}_{3}$ minerals poses a geochemical problem. The same mineral was encountered in sediment layers with shear strength maxima from the Norwegian Sea (core 055; Figure 6f).

Three stages of cementation were distinguished: (1) pores with no diagenetic imprint (Figure 6a), (2) pores with crustlike micritic cementation of the wall matrix (Figures $6 \mathrm{~b}, 6 \mathrm{c}$ and $6 \mathrm{~g}$ ), (3) pores with cemented wall matrix, crystal carpets, and other signs of advanced diagenesis such as crystal overgrowth on coccoliths and recrystallization of foraminifers (Figures $6 c, 6 d, 6 e, 6 f, 6 g, 6 h$ ).

The observed cementation of near-surface sedi- ments is not a mere artifact. Artificial, i.e., postcoring crystal growth is expected to affect all samples to a similar degree, whereas both the crystal carpets and the micritic crusts are confined to sediments with a shear strength maximum. Furthermore, an extremely careful sample treatment with a continuous cooling chain at $10^{\circ}-12^{\circ} \mathrm{C}$ from shipboard sampling until drying in the desiccator has proven effective during many previous studies of deep-sea sediments to preclude any artificial growth of crystals. However, the crystal growth linked to the shear strength maxima did not vary, either by extent or by intensity, as a result of a more or less careful sample treatment during the course of this study.

Thus the observed cementation appears to be of true early diagenetic origin, and the outlined spikes of apparent overconsolidation are the result of very early diagenetic cementation processes.

\section{Possible Scenario of Early Diagenetic Cementation in Deep-Sea Sediments}

More than a decade ago, Roth and Berger [1975] reported crystal overgrowth on coccoliths in recent pelagic sediments from the Pacific, especially from the depth range of the lysocline. Adelseck et al. [1973] suggested that this precipitation of $\mathrm{CaCO}_{3}$ happens simultaneously with selective dissolution of less resistant, for example, for example, aragonitic shells in the surface sediment. The flux and decay of organic matter may play the crucial role in these early diagenetic processes [Berner, 1980] and are, in part, enhanced by bioturbation, which is much more effective in subsurface elemental transport than molecular diffusion in the pore water [Berger et al., 1983].

However, all these aspects still leave open the decisive question, which special factors could induce a cementation that is restricted to thin layers only a few decimeters below the sediment surface and to a few further critical stratigraphic horizons farther downcore. More directly, which unusual events in the depositional environment might be suitable to produce such short-term but widespread marked increases in the "diagenetic potential" of deep-sea sediments [Schlanger and Douglas, 1974]?

In theory, the cemented subsurface beds do not need to be related to any specific "event" at all. They might be merely a transient product of excess saturation in the pore water of a subsurface horizon that gradually shifts upward in the profile with the 

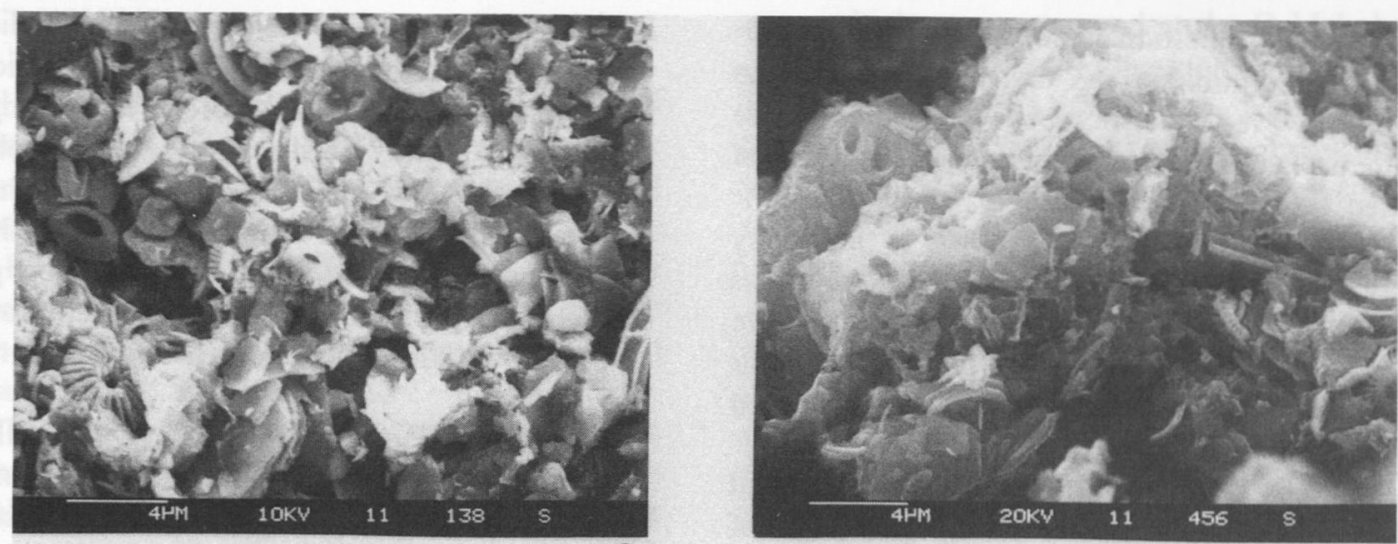

A
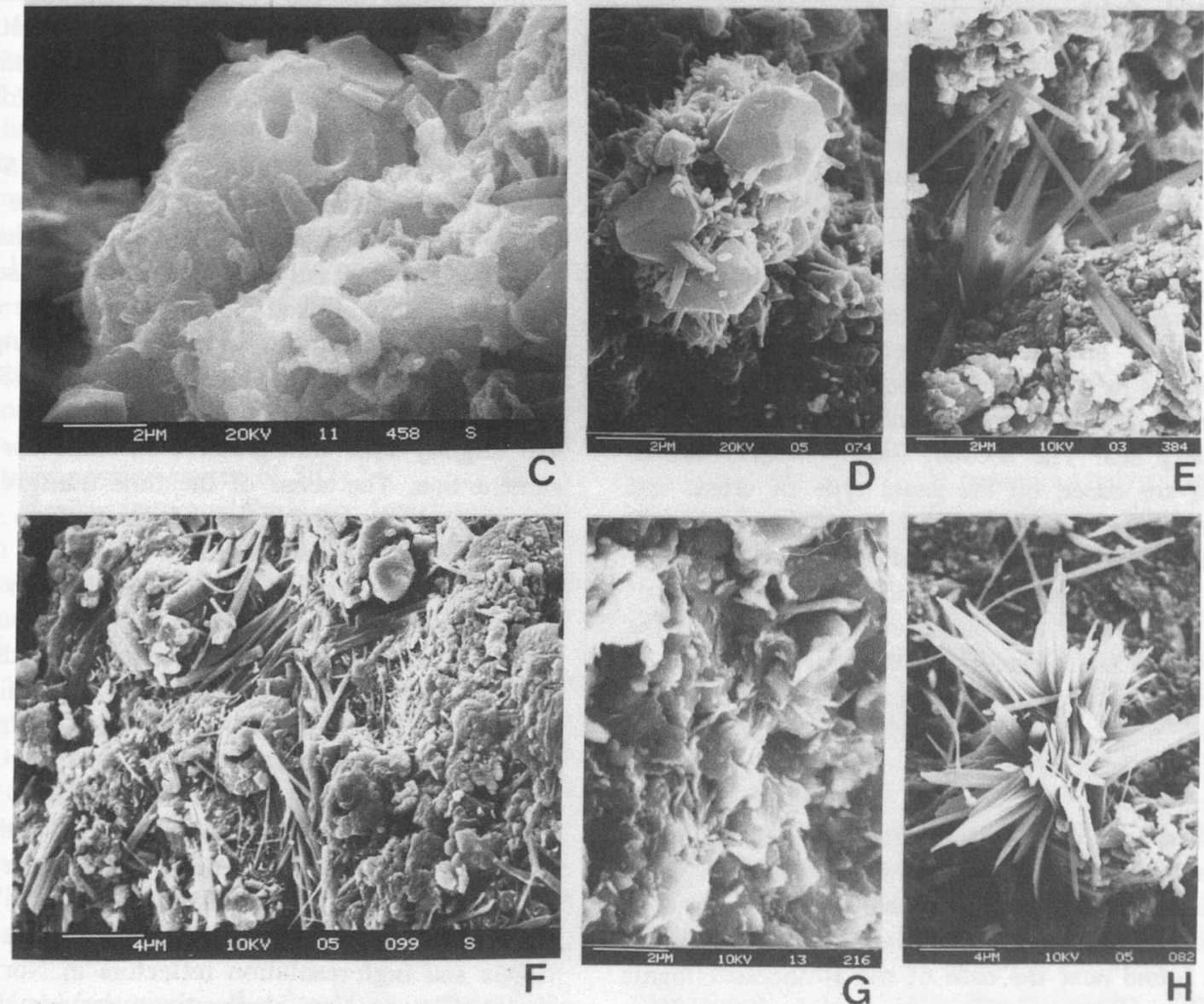

Fig. 6. Stereoscan microscope exposures of microfabrics in the sediment showing (a) pores with no diagenetic imprint visible (sample from below the shear strength spikes), (b) pores with crustlike micritic cementation of wall matrix (overview), (c) pores with cemented wall matrix (detail), (d) calcite and (e) aragonite crystals, overgrowth on pore wall, (f) quartz overgrowth, (g) crust of unknown silicate in sample from the Norwegian Sea, (h) unknown silicate crystals from the tropical Atlantic. 
accumulation of additional sediment and is succeeded by redissolution of the crystals deeper in the profile. However, the number of second shear strength peaks and of older, similarly pronounced indurated layers farther downcore (Figure 5) contradicts this explanation. Moreover, it is highly unlikely that mature crystal carpets of minerals as different as calcite, aragonite, and quartz have completely disappeared directly below the shear strength spikes without leaving any trace preserved in the pore volume.

The topmost cemented horizons in the equatorial Atlantic with their average stratigraphic age of 6000-7000 years B.P. follow up to $8 \mathrm{~cm}$, i.e., a few thousand years, above the widespread $\mathrm{Fe}^{-}$and Mn-coated layers, which we observed in our cores in harmony with the findings of McGeary and Damuth [1973] and Richardson [1974]. However, the SSMs match precisely a widespread, well-dated $\mathrm{CaCO}_{3}$ preservation maximum that lasted 2000 years [DuBois and Prell, 1985]. This exact timing requires a common mode of origin. Moreover, it suggests that some uncommon, short-lived paleoceanographic events linked to the peak Holocene may have provided the necessary no-analogue conditions to trigger the unusual processes of early diagenetic cementation near the sediment surface in the deep sea. The second, mostly weaker SSMs, which are based on the same type of crusts and crystal carpets and occurred about 14,500-15,000 years B.P., require a similar regime of cementation. This may have happened at the onset of Termination IA, when the plankton production in the high-productivity belts of the ocean started to decrease significantly [Berger and Keir, 1984; Sarnthein et al., 1987, 1988] and the reduced carbon flux possibly led to an improved $\mathrm{CaCO}_{3}$ preservation in the deep sea. However, the details of this second SSM horizon cannot be fully explained yet. The upper SSMs may be interpreted as the result of a preservational event, this time in the context of aragonitic, pteropod-rich sediment beds found near the base of the Holocene climatic optimum [Berger, 1977; Berger et al., 1983]. Their deposition reached down to more than $4200 \mathrm{~m}$ water depth, i.e., far below the present aragonite compensation depth, which in general does not exceed $3200 \mathrm{~m}$ [Ganssen and Lutze, 1982]. This excursion of the aragonite compensation depth (ACD) created an abnormal reservoir of a highly soluble $\mathrm{CaCO}_{3}$ mineral in the deep-sea sediments, which was available for subsequent dissolution and reprecipitation processes upcore. This setting may have caused the SSMs in the mid-Holocene. However, the shear strength spikes during analogue and reversed phases of climatic change in the past are still poorly understood in terms of their precise stratigraphic position and formational environment, although conditions analogous to the Holocene may be considered.

The chemical reactions that have controlled the nearby precipitation of quartz and other unidentified silicate crystals close to carbonate precipitates in sediments of the east Atlantic proximal to west Africa remain to be explained. Carbonates and silicates record counteractive $\mathrm{pH}$ environments, and yet they occur together. It may be interesting to note that sulfur concentrations reach a distinct minimum along with the SSMs.

By contrast, the SSMs in the Norwegian Sea are solely based on the unidentified ( $\mathrm{Fe}$ ) silicate crusts and, hence, on a geochemical environment that may be defined more easily. In a number of cases, the environment is linked to a distinct Fe-coated horizon at Termination I and, more interestingly, to the neighborhood of a diatom-rich layer [Stabell, 1986], which may form a short-term uncommon and slightly time transgressive resource for silica cementation. The sense of the time transgressivity of our shear strength maxima (from north to south), however, cannot be explained.

Cemented layers that form shear strength spikes such as in Figure 5 are likely to produce distinct reflectors in high-resolution seismic records. The SSM spikes show approximately the same thickness as pelagic $\mathrm{CaCO}_{3}$ layers, which produce frequent impedance shifts that result in narrow-spaced $3.5-\mathrm{kHz}$ reflectors and multiple seismic interferences characteristic of deep-sea sediments [Mayer, 1979, 1980; Mienert, 1986]. Indeed, H. Kassens and E. Vogelsang [unpublished manuscript, 1988] were able to correlate with great detail SSMs and high-resolution reflectors in Norwegian Sea sediments. Our observations provide, for the first time, a link between physical properties and short-term, very specific, and often recurring paleoceanographic events during the Quaternary. This link implies that events of deepwater chemistry can be documented in seismic stratigraphy and traced, at least by theory, across the ocean. 


\section{CONCLUSIONS}

1. Late glacial to Holocene pelagic sediments of the equatorial Atlantic are characterized by a pronounced shear strength maximum, i.e., by indurated beds which center in age at $7000 \pm 1000$ years B.P. and 15,000-14,500 years B.P.. A similar maximum marks the sediment profiles of the Norwegian Sea, but it is time transgressive and dates at $13,500-8,500$ years B.P..

2. The indurated beds are caused by early diagenetic cementation of near-surface sediments by calcite, aragonite, quartz, and other silicate minerals not yet identified that form the crusts in sediment vugs of the Norwegian Sea.

3. In the low-latitudinal Atlantic, the uncommon near-surface cementation by $\mathrm{CaCO}_{3}$ minerals about 7000 years ago enables, for the first time, one to establish a link between physical properties and events of deepwater chemistry. The shear strength maxima were possibly coupled with an abnormal reservoir of highly soluble aragonite, which in turn may be linked to a thin pteropod-rich sediment layer deposited far below the present aragonite compensation depth toward the end of glacial Termination I. On the other hand, the cemented horizons of Norwegian Sea sediments are paralleled by an uncommon diatom-rich bed as a possible and time transgressive source of $\mathrm{SiO}_{2}$.

4. Similar indurated beds are found near peak warm stages and warm substages during glacial stages throughout the Quaternary are little understood, but they may reflect comparable depositional regimes.

5. When buried by more sediments, the shear strength spikes are expected to create, like thin $\mathrm{CaCO}_{3}$ beds, distinguished widespread $3.5-\mathrm{kHz}$ reflectors. This link indeed has been observed in a few sediment sections and may form the potential backbone of a high-resolution seismic stratigraphy of Pleistocene pelagic sediments and inherent events of deepwater chemistry in the Atlantic.

Acknowledgments. We thankfully acknowledge valuable help and stimulating discussions with $\mathrm{F}$. C. Kögler, P. Holler, and W. H. Berger and, furthermore, the advise and critical comments of $\mathrm{C}$. Samtleben in interpreting our observations at the stereoscan microscope. E. Vogelsang and U. Pflaumann provided unpublished $\delta^{18} \mathrm{O}$ curves and ${ }^{14} \mathrm{C}$ ages, which were measured at the C-14 Laboratory of Kiel University under the kind supervision of $\mathrm{H}$. Willkomm and $\mathrm{H}$. Erlenkeuser. Microprobe analyses were carried out at the Department of Mineralogy and Petrology of Kiel University with the support of D. Ackermand; some further scanning electron microscope studies were done at the Alfred Wegener Institut Bremerhaven with the help of G. Kuhn. We thank D. Rea, W. Broecker, and anonymous reviewers for numerous valuable suggestions to improve the manuscript. Finally we like to thank K. H. Baumann and A. Altenbach for valuable help on editing the manuscript. This research was generously funded by the German Science Foundation (DFG grant Sa 207/24) and, later on, by the "Sonderforschungsbereich 313 " at Kiel University (contribution 40).

\section{REFERENCES}

Adelseck, C. G., G. W. Greehan and P. H. Roth, Experimental evidence for the selective dissolution and overgrowth of calcareous nannofossils during diagenesis, Geol. Soc. Am. Bull., 84, 2755-2762, 1973.

Almagor, G., A review: Marine geotechnical studies at continental margins, Rep. MG/79/3, pp. 1-100, Geol. Surv. of Israel, Jerusalem, 1979.

Almagor, G. and G. Wiseman, Analysis of submarine slumping in the continental slope off the southern coast of Israel, Mar: Geotechnol, 2, 349-388, 1977.

Bard, E., M. Arnold, J. C. Duplessy, J. Duprat and J. Moyes, Bioturbation effects on abrupt climatic changes recorded in deep sea sediments: Correlations between ${ }^{18} \mathrm{O}$ profiles and accelerator ${ }^{14} \mathrm{C}$ dating, in Abrupt Climatic Change: Evidence and Implications, ASI Ser., vol. C, edited by W. H. Berger and L. D. Labeyrie, pp. 263-278, NATO, Brussels, 1987.

Berger, W. H., Deep-sea carbonate and the deglaciation preservation spike in pteropods and foraminifera, Nature, 269, 301-303, 1977.

Berger, W. H., Deep-sea carbonate: Pteropod distribution and the aragonite compensation depth, Deep Sea Res., 25. 447-452, 1978.

Berger, W. H. and T. C. Johnson, Deep-sea carbonates: Dissolution and mass wasting on Ontong-Java Plateau, Science, 192, 785-787, 1976. 
Berger, W. H. and R. S. Keir, Glacial-Holocene changes in atmospheric $\mathrm{CO}_{2}$ and the deep-sea record, in Climate Processes and Climate Sensitivity, Geophys. Monogr. vol. 29, edited by J. E. Hansen and T. Takahashi, pp. 337-351, AGU, Washington, D. C., 1984.

Berger, W. H., R. C. Finkel, J. S. Killingley and V. Marchig, Glacial-Holocene transition in deep-sea sediments: Manganese-spike in the eastern equatorial Pacific, Nature, 303, 231-233, 1983.

Berner, R. A., Early diagenesis: A Theoretical Approach, 224 pp., Princeton University Press, Princeton, N. J., 1980.

Bjerrum, L., Geotechnical problems involved in foundations of structures in the North Sea, Geotechnique, 23(3), 319-358, 1973.

Boyce, R. E., Definition and laboratory technique of computing sound velocity parameters and wet water content, wet bulk density and porosity by gravity and gamma ray attenuation technique, Initial. Rep. Deep Sea Drill. Proj., 17, 931-958, 1976.

Broecker, W. S., M. Andree, W. Wölfli, H. Oeschger, G. Bonani, J. P. Kennett and D. Peteet, The chronology of the last deglaciation: Implications to the cause of the Younger Dryas event, Paleoceanography, 3, 1-19, 1988.

Cita, M. B. and G. Spezzibottiani, Late Neogene paleoenvironemnt studies on carbonate content, grain size, and dissolution, cores 1-57 (DSDP site 397), Initial Rep. Deep Sea Drill. Proj., Part A, 47, 671-682, 1979.

DuBois, L. G. and W. Prell, Early Holocene carbonate preservation spike: Evidence from the eastern equatorial Atlantic, (abstract), Eos Trans. AGU, 66, 292, 1985.

Duplessy, J. C., G. Delibrias, J. L. Turon, C. Pujol and J. Duprat, Deglacial warming of the northeastern Atlantic Ocean. Correlation with the paleoclimatic evolution of the European continent, Palaeogeogr. Palaeoclimatol. Palaeoecol., 35, 121-144, 1981.

Duplessy, J. C., M. Arnold, P. Maurice, E. Bard, J. Duprat and J. Moyes, Direct dating of the oxygen isotope record of the last deglaciation by ${ }^{14} \mathrm{C}$ accelerator mass spectrometry, Nature, 320, 350352, 1986.

Einsele, G., Mass physical properties of Pliocene to Quaternary sediments in the Gulf of California, Deep Sea Drilling Project leg 64, Initial Rep. Deep Sea Drill. Proj., Part II, 64, 512-529, 1982.
Einsele, G. and F. W. Werner, Zusammensetzung, Gefüge und mechanische Eigenschaften rezenter Sedimente vom Nildelta, Roten Meer und Golf von Aden, Meteor Forschungsergeb., Reihe C, I, 21-42, 1968.

Ganssen, G. and G. F. Lutze, The aragonite compensation depth of the northeastern Atlantic continental margin, Meteor Forschungsergeb., Reihe C, 36, 57-59, 1982.

Gerlach, S. A., J. Thiede, G. Graf, and F. W. Werner, Forschungsschiff Meteor, Reise 2: Berichte der Fahrtleiter, Ber. Sonderforschungsbereich 313, 4, pp. 1-140, Univ. Kiel, Kiel, Fed. Repub. of Ger., 1986.

Holler, P. R., Geotechnical properties of Antarctic deep sea sediments, Meteor Forschungsergeb., Reihe C, 39, 23-36, 1985.

Holler, P. R., Sedimentäre Rutschmassen in der Tiefsee, Ber: 23, pp. 1-141, Geol.-Paläontolo. Inst. Univ. Kiel, Kiel, Fed. Rep. of Ger., 1988.

Johnson, T. C., E. L. Hamilton and W. H. Berger, Physical properties of calcareous ooze: Control by dissolution at depth, Mar: Geol., 24, 259-277, 1977.

Kassens, H., Verteilung von physikalischen Sediment- eigenschaften in oberflächennahen Sedimenten des äquatorialen Ostatlantiks, M.Sc. thesis, 81 p., Univ. Kiel, Kiel, Fed. Rep. of Ger., 1985.

Kögler, F. C., Das Kastenlot, Meyniana, 13, pp. 1-7, 1963.

Kögler, F. C., Geotechnical properties of recent marine sediments from the Arabian Sea and Baltic Sea, in Marine Geotechnique, edited by A. F. Richards, pp. 170-176, University of Illinois Press, Urbana, 1967.

Mayer, L. A., Deep sea carbonates: Acoustic, physical, and stratigraphic properties, J. Sediment. Petrol., 49, 819-836, 1979.

Mayer, L. A., Deep sea carbonates: Physical property relationships and the origin of highfrequency acoustic reflectors, Mar. Geol., 38, 165-183, 1980.

McGeary, D. F. R. and J. E. Damuth, Postglacial iron-rich crusts in hemipelagic deep-sea sediments, Geol. Soc. Am. Bull., 84, 1201-1212, 1973.

Mienert, J., Akustostratigraphie im äquatorialen Ostatlantik: Zur Entwicklung der Tiefenwasserzirkulation der letzten 3.5 Mio. J., Meteor Forschungsergeb., Reihe C., 40, 19-86, 1986. 
Mix, A. C. and W. F. Ruddiman, Structure and timing of the last deglaciation: oxygen-isotope evidence, Quat. Sci. Rev., 4, 59-108, 1985.

Prell, W. L., J. Imbrie, D. G. Martinson, J.J. Morley, N. G. Pisias, N. J. Shackleton and H. F. Streeter, Graphic correlation of oxygen isotope stratigraphy application to the Late Quaternary, Paleoceanography, 1 (2), pp. 137-162, 1986.

Richards, A. F., Investigations of deep-sea sediments cores, II: mass physical properties, Tech. Rep. 106, 145 p., U. S. Navy Hydrogr. Office, Washington D.C., 1962.

Richards, A. F. and E. L. Hamilton, Investigations of deep-sea sediment cores, III: consolidation , in Marine Geotechnique, edited by A. F. Richards, pp. 93-117, University of Illinois Press, Urbana, 1967.

Richardson, D. S., The origin of iron-rich layers in sediments of the western equatorial Atlantic Ocean, Ph.D. thesis, 250 pp., Columbia Univ., New York, 1974.

Roth, P.H. and W. H. Berger, Comparison of dissolution pattern in coccoliths and foraminifera, Spec. Publ. Cushman Found. Foraminiferal. Res., 13, 87-113, 1975.

Sarnthein, M., H. Erlenkeuser and R. Zahn, Termination I: The response of continental climate in the subtropics as recorded in deep-sea sediments, Bull. Inst. Geol. Basin Aquitaine, 31, 393-407, 1982.

Sarnthein, M., F. C. Kögler and F. Werner, Forschungsschiff Meteor, Reise Nr. 65, Berichte der wissenschaftlichen Leiter, Ber. 2, 90 p., Geol.-Paläontol. Inst. Univ. Kiel, Kiel, Fed. Repub. of Ger., 1983.

Sarnthein, M., F. Haake, L. Mayer, U. Pflaumann, M. Springer, F. Werner and H. Wiederhold, Bericht über die POLARSTERN-Fahrt ANT IV/1C in den Äquatorialen Atlantik GEOTROPEX'85. Dakar - Rio de Janeiro, Ber. 11, 35 p., Geol.- Paläontol. Inst. Univ. Kiel, Kiel, Fed. Repub. of Ger. 1985.

Sarnthein, M., K. Winn and R. Zahn, Paleoproductivity of oceanic upwelling and the effect on atmospheric $\mathrm{CO}_{2}$ and climatic change during deglaciation times, in Abrupt Climatic Change, edited by W. H. Berger and L. D. Labeyrie, pp. 311-337, D. Reidel, Hingham, Mass., 1987.

Sarnthein, M., K. Winn, J. C. Duplessy and M.R. Fontugne, Global variations of surface ocean productivity in low and mid latitudes: Influence on $\mathrm{CO}_{2}$ reservoirs of the deep ocean and atmosphere during the last 21,000 years, Paleoceanography 3, pp. 361-399, 1988.

Schlanger, S. O. and R. G. Douglas, The pelagic ooze-chalk-limestone transition and its implications for marine stratigraphy, in Pelagic Sediments: on Land and under the Sea, edited by H. J. Hsu and H. C. Jenkyns, pp. 117-148, Blackwell Scientific Publications, Oxfort, London, $\quad$ Edingburh, Melbourne, 1974.

Stabell, B., A diatom maximum horizon in upper Quaternary deposits, Geologische Rundschau, 75/1, 175-184, 1986.

Stein, R., Rapid grain-size analysis of silt and clay fractions by Sedigraph 5000 D: Comparsion with coulter counter and Atterberg methods, J. Sediment. Petrol., 55, 590-593, 1985.

Thunell, R. C., Carbonate dissolution and abyssal hydrography in the Atlantic Ocean, Mar: Geol., 47, 165-180, 1982.

Vogelsang, E., Hochauflösende Zeitreihen von den Sedimenten der Termination I im äquatorialen Ost- atlantik, M.Sc. thesis, 85 p., Univ. Kiel, Kiel, Fed. Repub. of Ger., 1985.

Wise, S. W., Chalk formation: Early diagenesis, in The Fate of Fossil Fuel CO2 in the Oceans, edited by N. R. Andersen and A. Malahoff, pp. 717-739, Plenum, New York, 1977.

H. Kassens and M. Sarnthein, GeologischPaläontologisches Institut, Universität Kiel, Ludewig Meyn Strasse 10, D-2300 Kiel, Federal Republic of Germany.

(Received October 5, 1987;

revised January 11, 1989;

accepted January 16, 1989.) 